\title{
Buried archeological remains connected to the Greek-Roman harbor at Tindari (north-east Sicily): results from geomorphological and geophysical investigations
}

Carla Bottari ${ }^{1,}{ }^{\star}$, Stefano Urbini ${ }^{1}$, Marcello Bianca ${ }^{3}$, Maria D'Amico ${ }^{2}$, Marco Marchetti ${ }^{1}$, Francesco Pizzolo ${ }^{2}$

${ }^{1}$ Istituto Nazionale di Geofisica e Vulcanologia, Sezione Roma 2, Rome, Italy

${ }^{2}$ Università di Messina, Osservatorio Sismologico, DIC, Messina, Italy

${ }^{3}$ Università della Basilicata, Dipartimento di Strutture, Geotecnica, Geologia applicata all'Ingegneria, Potenza, Italy

\section{Article history}

Received March 12, 2010; accepted December 16, 2011.

\section{Subject classification:}

Buried harbor structures, Geophysical investigation, Horizontal-to-vertical spectra ratio method, Stratigraphy, Digital terrain model.

\begin{abstract}
In recent years, detailed geoarcheological investigations have been carried out to search for traces of the ancient Tindari harbor (north-east Sicily, Italy). A digital terrain model supported the hypothesis that 2,000 yr ago the Oliveri Basin was a suitable landing place that was protected from prevailing winds. This model was generated from uplift data, sea level changes, historical cartographic data and three-dimensional reconstruction of the sedimentary succession of the cover. The present position of some historical buildings represent an archeological marker of the shoreline progression. Recent excavations during the construction of the Messina-to-Palermo motorway brought to light some portions of an ancient archeological complex. The thickness of the walls and the volume of the collected archeological material suggests dating between the 1 st century $B C$ and the 4 th century $A D$. After that time, heavy environmental changes due to human activities in the area led to inaccurate underestimation of the role of Tindari harbor in the past. A geophysical investigation was carried out in the area surrounding the archeological complex to search for new buried structures related to the ancient settlement, and to be open to any results of the paleotopographic reconstruction of the area. The applied geophysical techniques included passive seismic and ground-penetrating radar. This survey indicates the presence of buried structures, such as walls and floors, that probably belong to a Roman villa. Furthermore, it defines the depth of the Holocene sedimentary cover of the Oliveri coastal plain, which strengthens the hypothesis formulated for its morphological evolution.
\end{abstract}

\section{Introduction}

A recent survey carried out as part of a study of the geomorphological evolution of the Oliveri coastal plain supports the hypothesis that Tindari harbor was located south-east of the Tindari Promontory, between the castle and Carruba Valley (Figure 1b) [Bottari et al. 2009a, 2009b]. The reconstruction of the ancient topography of the Tindari
Promontory and the Oliveri coastal plain was based on Holocene uplifted and submerged notches that indicate past sea levels (Figure 2). Along the western Tindari Cape coastline, two marine notches were found higher than the present day sea level. The most prominent of these notches lies between $5 \mathrm{~m}$ and $6 \mathrm{~m}$ above sea level, and was formed in the metamorphic rock outcropping in the area. A submerged notch lies $3 \mathrm{~m}$ below sea level. A recent digital terrain model (DTM) [Bottari et al. 2009a] was based on the assumption that in the 4th century BC the sea level was $5 \mathrm{~m}$ higher than the modern sea level. This is in agreement with the uplift rate data [Antonioli et al. 2006] and the sea level change in the Tyrrhenian Sea for the Late Holocene [Lambeck and Purcell 2005]. An average tectonic uplift rate of ca. $1.7 \mathrm{~mm} / \mathrm{yr}$ and a sea level rise of ca. $3 \mathrm{~m}$ to $5 \mathrm{~m}$ in the last 5,000 yr was estimated for the Milazzo peninsula.

The combined actions of the marine-fluvial dynamics produced progressive growth of the Oliveri coastal lowland and progression of the shoreline, which was responsible for the burial of some ancient buildings. As evidence of this, an ancient portal and a building located in the plain are currently buried by $2.0 \mathrm{~m}$ and $2.5 \mathrm{~m}$ of sediment, respectively. The 'migration' of three stores associated with tuna-fishing nets that were located near the shoreline further indicates the progression of the shoreline (Figure 1b). Using this evidence, it has been estimated that the shoreline advanced $800 \mathrm{~m}$ with respect to the ancient shore, which was originally close to Oliveri Castle.

The main goal of the present geophysical investigation was to test the reliability of this DTM through passive seismic methods. These were based on horizontal-to-vertical spectra ratios (HVSRs) and used ground-penetrating radar (GPR) to locate further buried archeological structures that were linked 

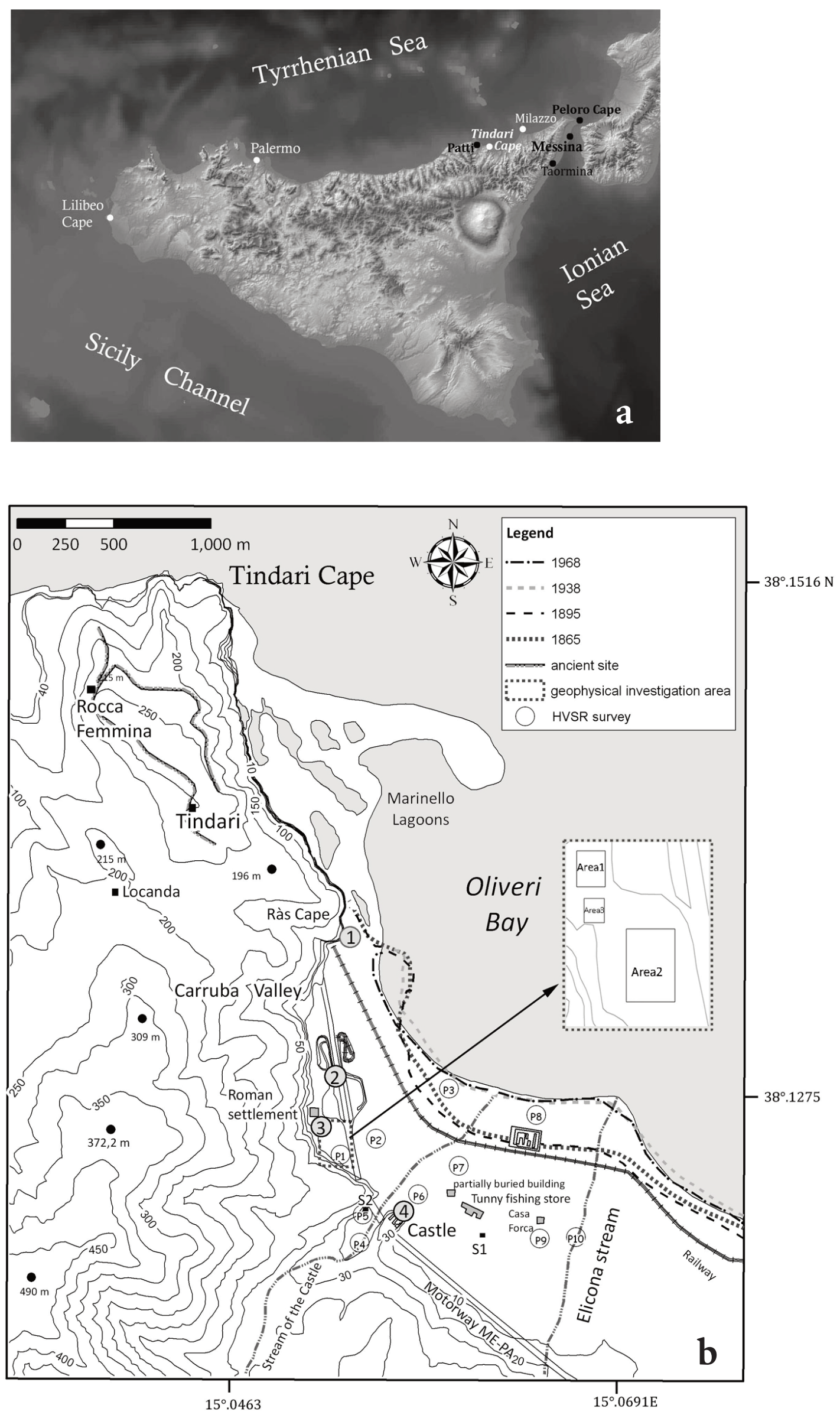

Figure 1. (a) Satellite picture of Sicily. (b) Map of the Tindari Cape Promontory and the Oliveri plain, and geomorphological reconstruction of the coastline from Elicona Stream to Tindari Cape Promontory, based on the Istituto Geografico Militare Italiano maps from 1865 to 1968 . The positions of the historical buildings, the iron rings (numbered 1 to 4), boreholes S1 and S2, and the microtremor measurements (P1-P10) are also shown. 
to Tindari harbor. The HVSRs allowed an assessment of the thickness of the Holocene stratigraphic succession of the Oliveri coastal plain at 10 measurement points. The heavy environmental changes due to anthropogenic activities in this area, such as the Palermo-to-Messina motorway and the construction of new buildings, have minimized the possibilities of finding new and undamaged buried structures related to the presence of a Roman villa. Nevertheless, some GPR profiles showed anomalies that appear to be caused by buried archeological remains.

\section{Geological background}

The Promontory of Tindari Cape is a part of the Tyrrhenian margin of the Peloritani Belt, which is composed of a set of south-verging tectonic units that have piled up since Oligocene times. The system is made up of different overlapping tectonic nappes that consist of terrains of the Hercynian basement rock covered by Meso-Cenozoic sedimentary deposits [Atzori and Vezzani 1974, Lentini and Vezzani 1975]. Resting on the entire complex, there is the discordant Flysch of Capo d'Orlando, a terrigenous formation of the lower Oligo-Miocene age [Lentini et al. 2000]. The geology is capped by sediments of recent origin (Holocene) that have been deposited in the marine and continental environments. These are colluvium of variable thicknesses that can be observed at the base of scarps and slopes or as accumulations of sediment in the floodplains or valley floors, in the beach deposits, and in particular, in the Marinello lagoons, which are located at the base of Tindari Cape (Figure 1).

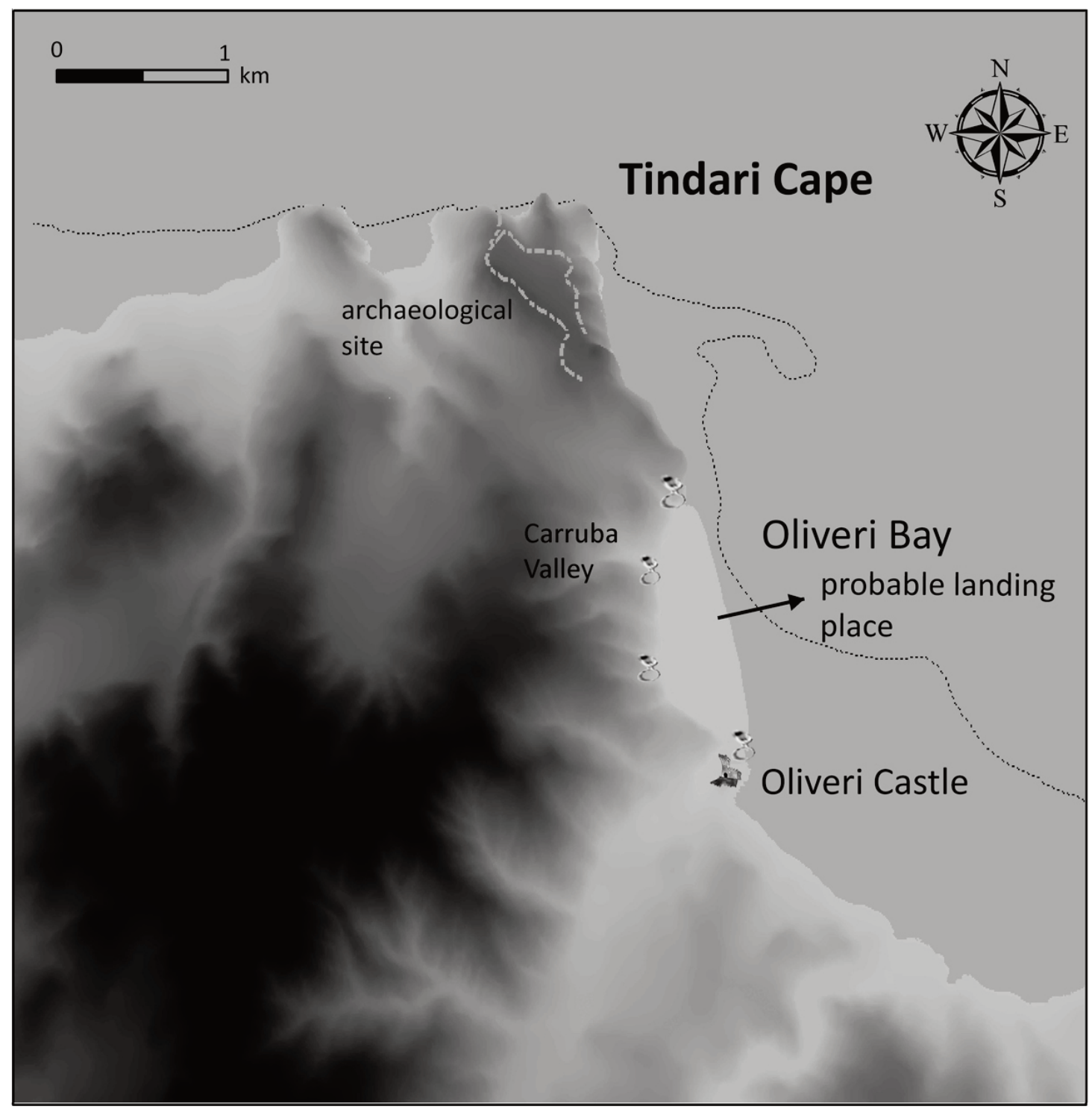

Figure 2. Digital terrain model showing Tindari archeological site, the probable landing place, the iron ring locations, and the present-day coastline (dashed line). The DTM was obtained by aerophotogrammetry in 1987, by Regione Sicilia (scale 1:10,000), and was built in the Gauss-Boaga reference system, in the zone East of the Monte Mario Meridian, with absolute coordinate values expressed in meters. 


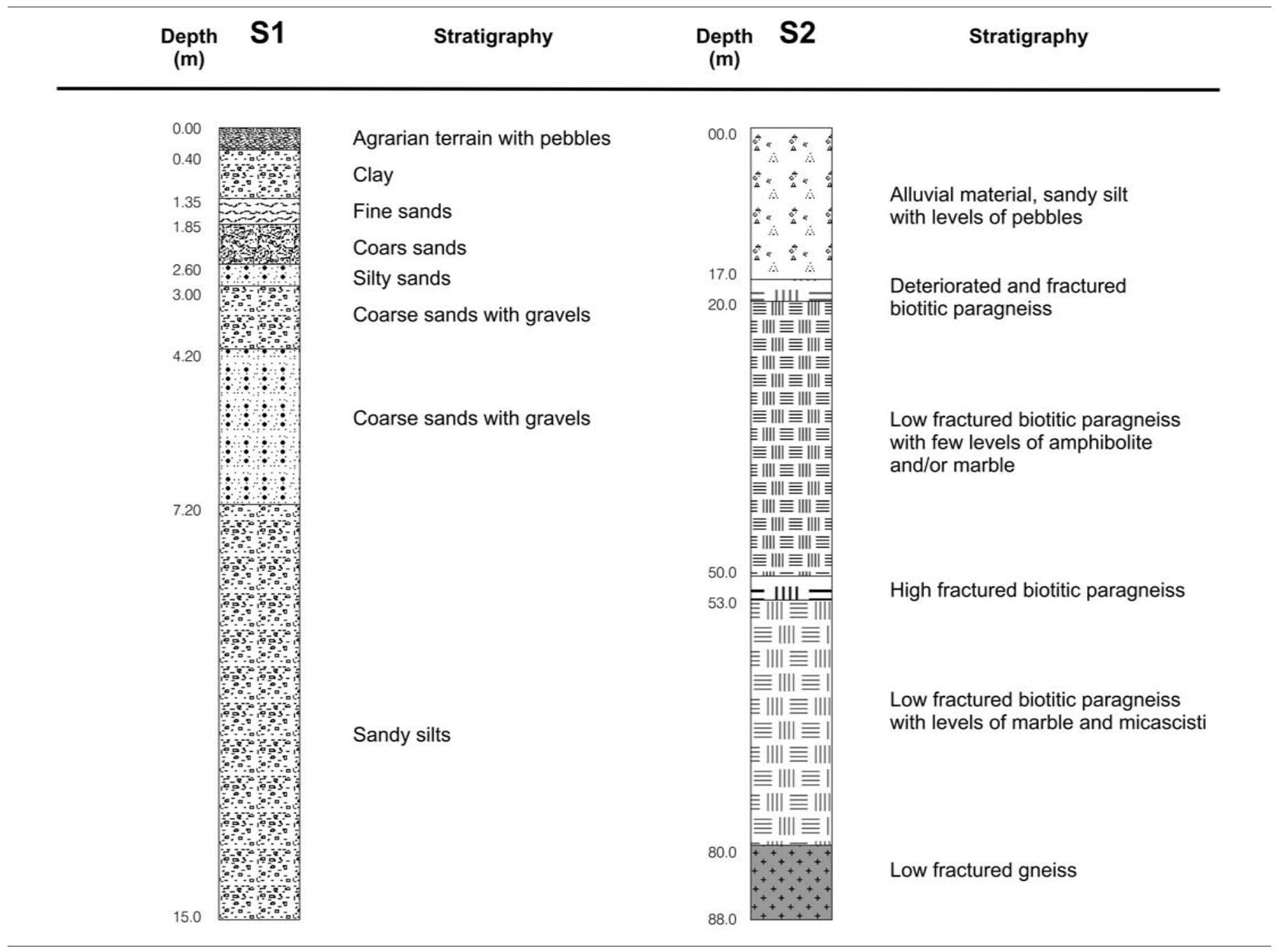

Figure 3. Stratigraphic successions of the $S 1$ and $S 2$ cores.

\subsection{Morphological evolution of the Oliveri shoreline}

The eastern coastal plain of Tindari Cape started to form in the Late Holocene. Over the last four centuries, the combined actions of marine and fluvial processes produced progressive and conspicuous growth of the plain. This resulted from deposition of eroded materials from the formations outcropping on the northern slope of the Nebrodi Mountains. Intense sedimentation that mainly came from Timeto River (adjoining Patti; Figure 1a) and Elicona River produced the progressive aggradation of the basin (Figure 1b). The progradation of the shoreline and the development of the Marinello lagoon system can be related to the cyclic climate changes that have occurred in the Mediterranean area since 2,500 yr BP [Ortolani and Pagliuca 1994, Rumsby and Macklin 1996, Allocca et al. 2000].

The Marinello lagoon system comprises a NNW-SSEoriented sandy-gravel formation, and it is characterized by shallow brackish waters. This system started to develop from the beginning of the 19th century. Since the Roman era, human modifications of the fluvial watershed (e.g. deforestation, agriculture) have accelerated the soil erosion of both the upland and lowland areas, which have produced significant geomorphological variations [Marriner and Morhange 2007]. The alluvial material conforms the Oliveri plain in which the village of Oliveri sits.

From descriptions of the coastline morphological conditions reported by coeval historical sources, the beginning of the progressive extension of the plain definitely occurred after the 16th century [Omodei 1560, Fazello 1574, Camilliano 1584, Spannocchi 1596]. A core (Figure 3, S1; see Figure 1b) was drilled to $15 \mathrm{~m}$ depth in the alluvial plain near the castle, and this showed several depositional events that occurred less than 5,000 yr ago [Trainiti 1997]. In particular, from the top, this S1 core shows a stratigraphic succession of sandy silt that changes to clay, then layers of fine sand and coarse sand, then silty sand that changes to coarse sand with gravel, and then layers of sandy silt (Figure 3, S1).

\section{The harbor of Tindari and archeological findings in the Oliveri coastal plain}

Beginning with its foundation in 396 BC, the fortified town of Tindari, in north-east Sicily (Italy) had a prominent military and trading role. Its strategic position in the 
Mediterranean Sea (Figure 1a) gave the town control of maritime traffic. To retain this prominence, Tindari must have had a harbor for its ships, but the remains of this harbor have been lost over the centuries.

Despite its predominantly military nature, Tindari mirrored the typical characteristics of the Greek colonies as a trading and economic center. Numismatic findings have provided a glimpse of the economic life: the dolphin, Poseidon, and ship's prow coin types confirm the maritime inclination of the town [Columba 1906, Arlotta 1996]. It seems likely, therefore, that trade was one of the most important mainstays of the Tindari economy. Its position was also strategic for the transport of goods [Consolo Langher 1977], and especially for the inland centers that exported wheat. Tindari was one of the Sicilian cities that probably had to pay the $5 \%$ portorium to Rome; this maritime tax was usually applied on goods moving in and out of ports [Scaramuzza 1937].

The harbor of Tindari mirrored the typical characteristics of Greek harbors of the time. It was in a natural sheltered basin, protected by prevailing winds (west, north-west and north winds), and close to the high coastal mountain, that forms the Tindari Promontory (Figure 1). Tindari harbor was visible from the sea and spaced at 20 to $70 \mathrm{~km}$ (about 1137 nautical miles) from the closest Sicilian harbors (Milazzo, Peloro and Messina) to garantee ships safe day by day transfers for sailing along the coast at speeds of 3 knots to 5 knots. Simple anchorages were also frequent for temporary stopovers, and mooring rings for smaller boats [Franco 1996].

On the Oliveri coastal plain, some remains of a Roman villa with annexed baths were brought to light in 1971 during the construction of the Messina-to-Palermo motorway (Scibona, personal communication). Shortly afterwards, the remains of an archeological complex were heavily damaged and looted. Recently, the area investigated has suffered new radical anthropogenic transformations. An excavation for the construction of a building in Area 3 (Figure 4) damaged a portion of the buried archeological complex, and at the same time, brought to light some further structures. The thick walls highlighted in the stratigraphic section and the volume of archeological material found on the surface (e.g. fragments of mosaic tesserae and cocciopesto floors, fragments of decorated plaster, and the lower portion of a marble statue depicting Artemides) (Figure 5) are proof of the importance of this site.

Near the motorway, an ancient wall was discovered, with iron moorings of about $30 \mathrm{~cm}$ in diameter and at least $2.5 \mathrm{~cm}$ in thickness. Other similar rings were still visible a few years ago at the base of Oliveri castle, at St. Leo and at Ràs Cape, at about $6 \mathrm{~m}$ to $8 \mathrm{~m}$ a.s.l. According to the archeologists of Messina Superintendence, the remains are of a Roman villa that probably belonged to Gneo Pompeo, which was mentioned by Cicero (IV, 46).

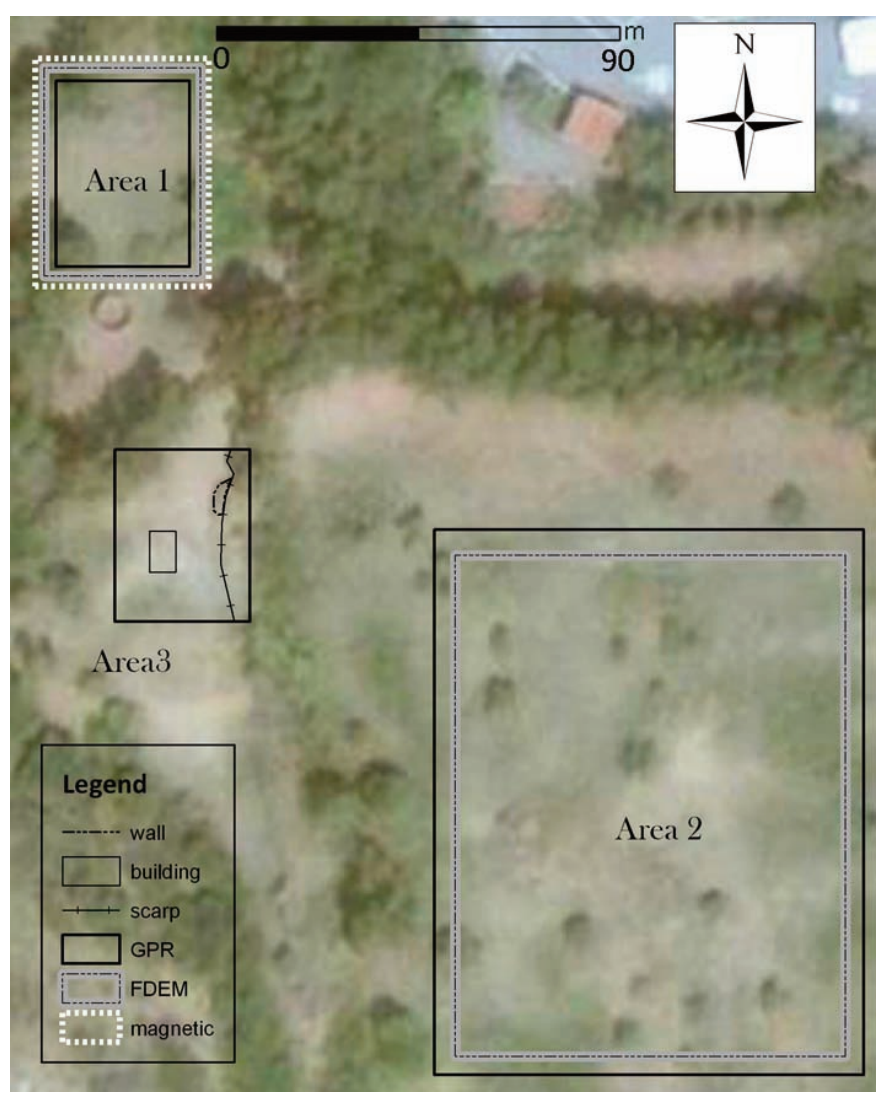

Figure 4. Map of the areas investigated by GPR.

\section{Geophysical survey}

An integrated geophysical survey was carried out at St. Leo, on the Oliveri coastal plain, which was designed to define the main stratigraphy of the area and to find any new archeological structures connected to the ancient harbor activities (Figures 1b, 4). The methods used in this survey were: passive seismic methods based on HVSRs and GPR. The GPR surveys covered a surface of $1.2 \mathrm{ha}$, over three areas that surround the archeological site (Figure 4). The main objective was to locate possible traces of buried archeological remains in Areas 1 and 3 (Figures 1b, 4). The survey was also conducted in Area 2, to define the possible extension of the same archeological complex and the presence of further buried remains.

Unfortunately, due to the heavy transformations connected with the construction of the motorway, it was not possible to produce any results in terms of anomalies in Area 1 and Area 2 . The most interesting results were produced by GPR prospection in Area 3.

\subsection{Horizontal-to-vertical spectra ratios}

The main application of the HVSR technique, beyond the common use for microzonation purposes, is for basin analysis studies. In particular, this geophysical method is applied to identify variations in resonance frequency with depth of sediments. HVSRs of ambient noise analysis were initially proposed by Nogoshi and Igarashi [1970, 1971], and updated by Nakamura [1989, 2000]. These use one single 

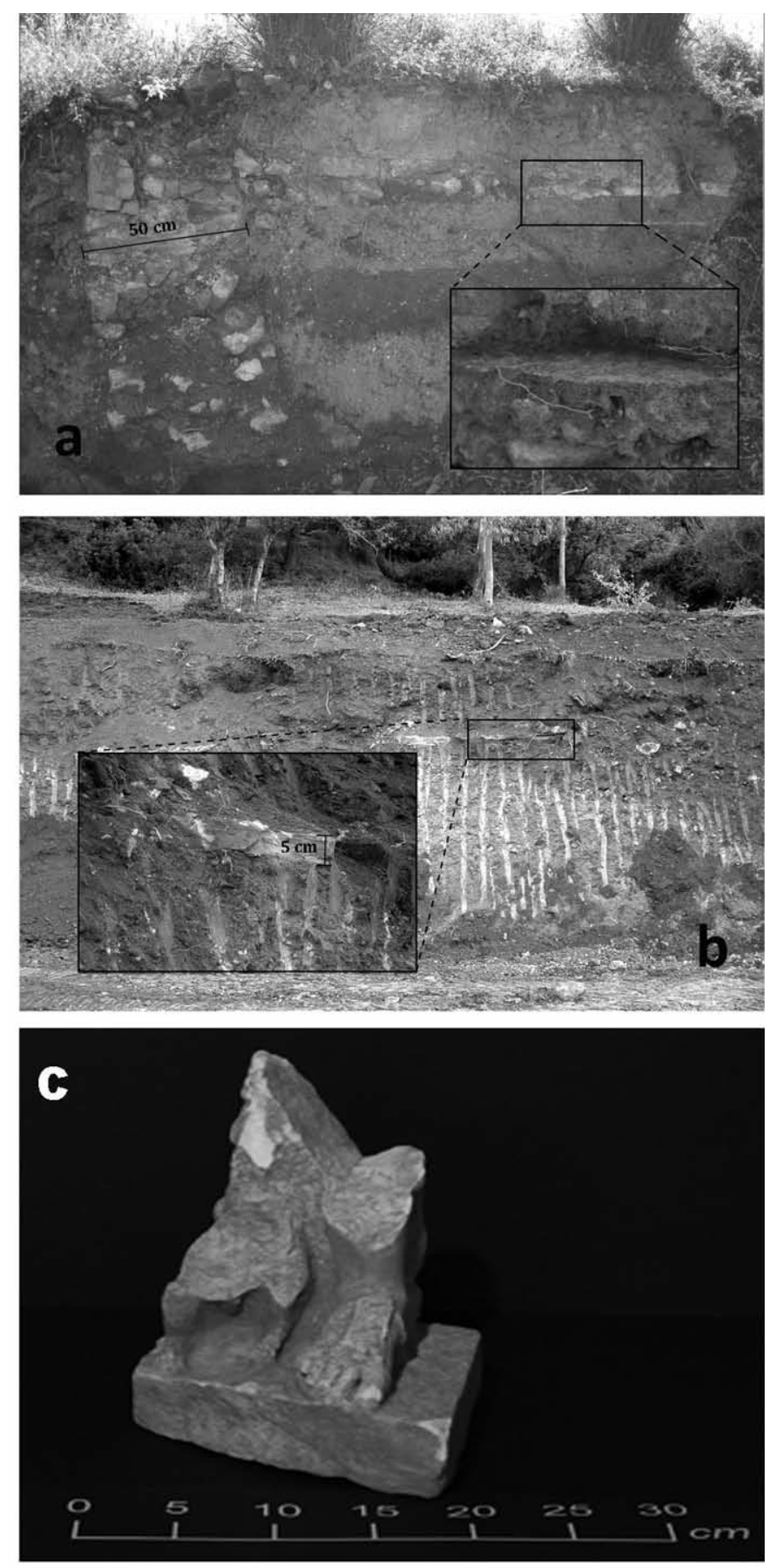

Figure 5. The St. Leo site. (a, b) Stratigraphic sections show two ancient structures corresponding to the Roman settlement. (c) Lower portion of a marble statue depicting Artemides.

station to record the ambient noise over a certain period of time in which the spectral ratios of the two horizontal components over the vertical component are calculated. The resulting curve generally shows a peak at the resonance frequency of the site. Moreover, recent observations have shown that the HVSR method is a reliable geophysical prospecting technique to estimate the first-order geometry of main seismic reflectors, like interfaces between alluvial material and the underlying bedrock [Ibs-von Seth and Wohlemberg 1999].

The Sesame project [2004] defined some criteria for a general consensus relating to the reliability of HVSR analysis. In particular, three criteria were defined for reliable HVSR curves, based on the relationships between the peak frequency and the window length, the number of significant cycles, and the standard deviation of the peak amplitude. Furthermore, six criteria for clear peak definition are based on the relationships between the peak amplitude and the level of the HVSR curve elsewhere, and the standard deviations of the peak frequency and its amplitude (the amplitude should decrease rapidly on each side). If all three criteria for a reliable curve, and at least five criteria for a clear peak, are satisfied, the frequency of the peak is considered to be the fundamental frequency of the sediments down to the first strong contrast in shear-wave velocity (Vs). With these criteria defined by the Sesame project [2004] fulfilled, ambient noise measurements were carried out at the ground surface at ten points distributed over the area investigated (Figure 1b, P1-P10).

The signals were recorded using a Tromino digital tromograph equipped with three orthogonal velocimeters and a global-positioning system receiver. This recorded the ambient noise generated by the Earth dynamics, atmospheric phenomena (e.g. sea waves and wind), and anthropic activities. Each measurement point was recorded for $20 \mathrm{~min}$ and sampled at $256 \mathrm{~Hz}$. Time histories were divided into 20-s windows, to remove transients, corrected for anomalous trends, tapered with a Bartlett function, and padded with zeros. Furthermore, for each window, the fast Fourier transform and amplitude spectrum were computed. The spectra were smoothed using a triangular function with a width equal to $10 \%$ of the central frequency. The horizontal components were obtained using quadratic averaging of the $\mathrm{N}-\mathrm{S}$ and E-W spectra components. The arithmetic averages of all of the horizontal-to-vertical component ratios represent the HVSR function. Finally, the Grilla software allows the use of the stratigraphic model of the soil obtained from the available borehole data (thickness of the geological layers and/or values of Vs of each layer obtained by downhole tests) to get synthetic HVSR curves for comparison with the experimental HVSR curves [Castellaro et al. 2005]. Once a good fit between the two sets of curves was obtained, the onedimensional (1D) stratigraphy of the soil was reconstructed, even for the measurement points where borehole data are not available.

\subsection{Ground-penetrating radar}

The GPR method is based on the reflection of an electromagnetic wave due to one or more discontinuities in the dielectric properties of the subsurface. Buried shallow walls and cavities in general generate strong contrasts in the field dielectric properties, and these provide targets for the GPR method [Annan and Cosway 1992, Jol and Smith 1992, Benson 1995, Daniels 1996, Basile et al. 2000]. The use of 

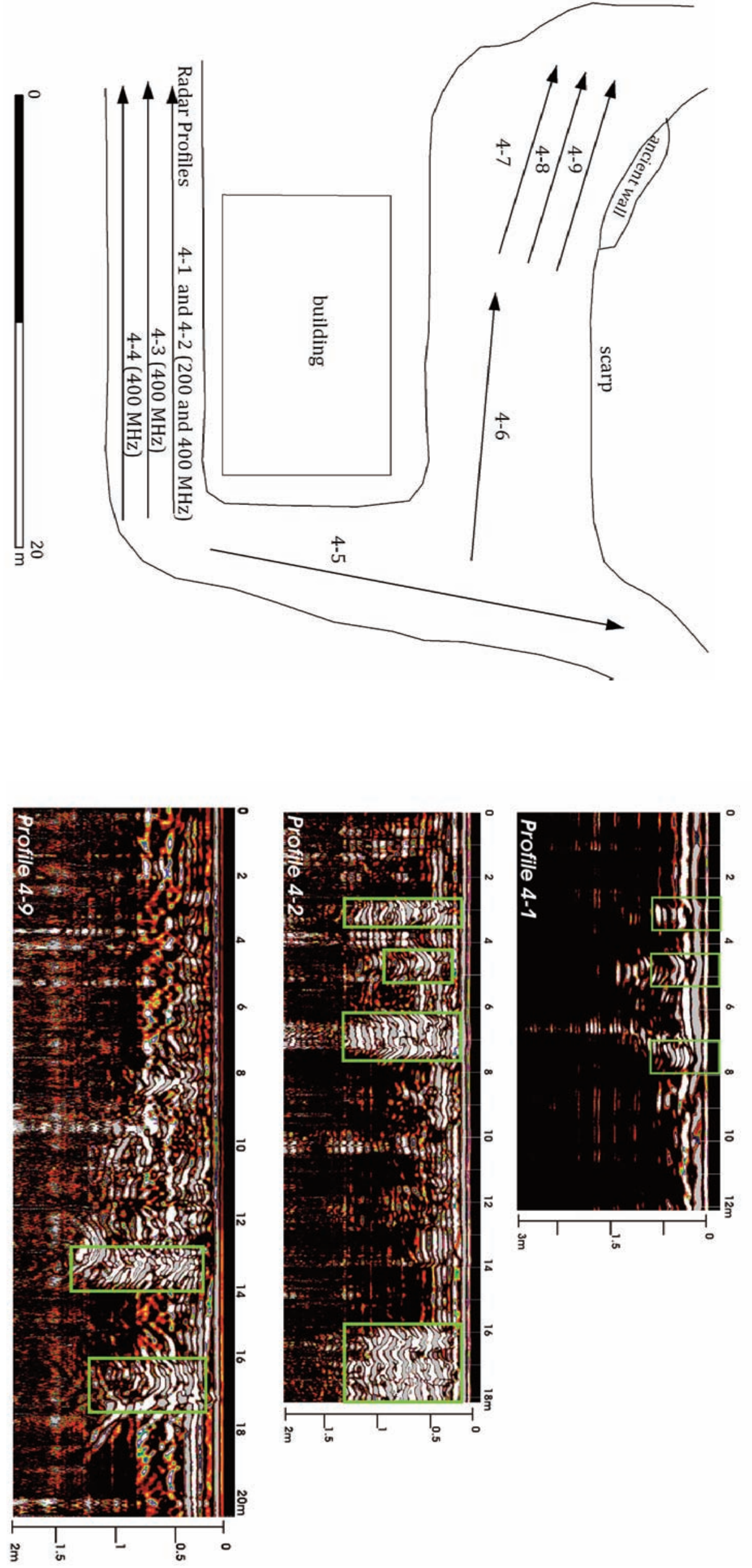

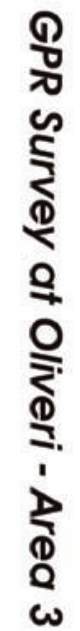



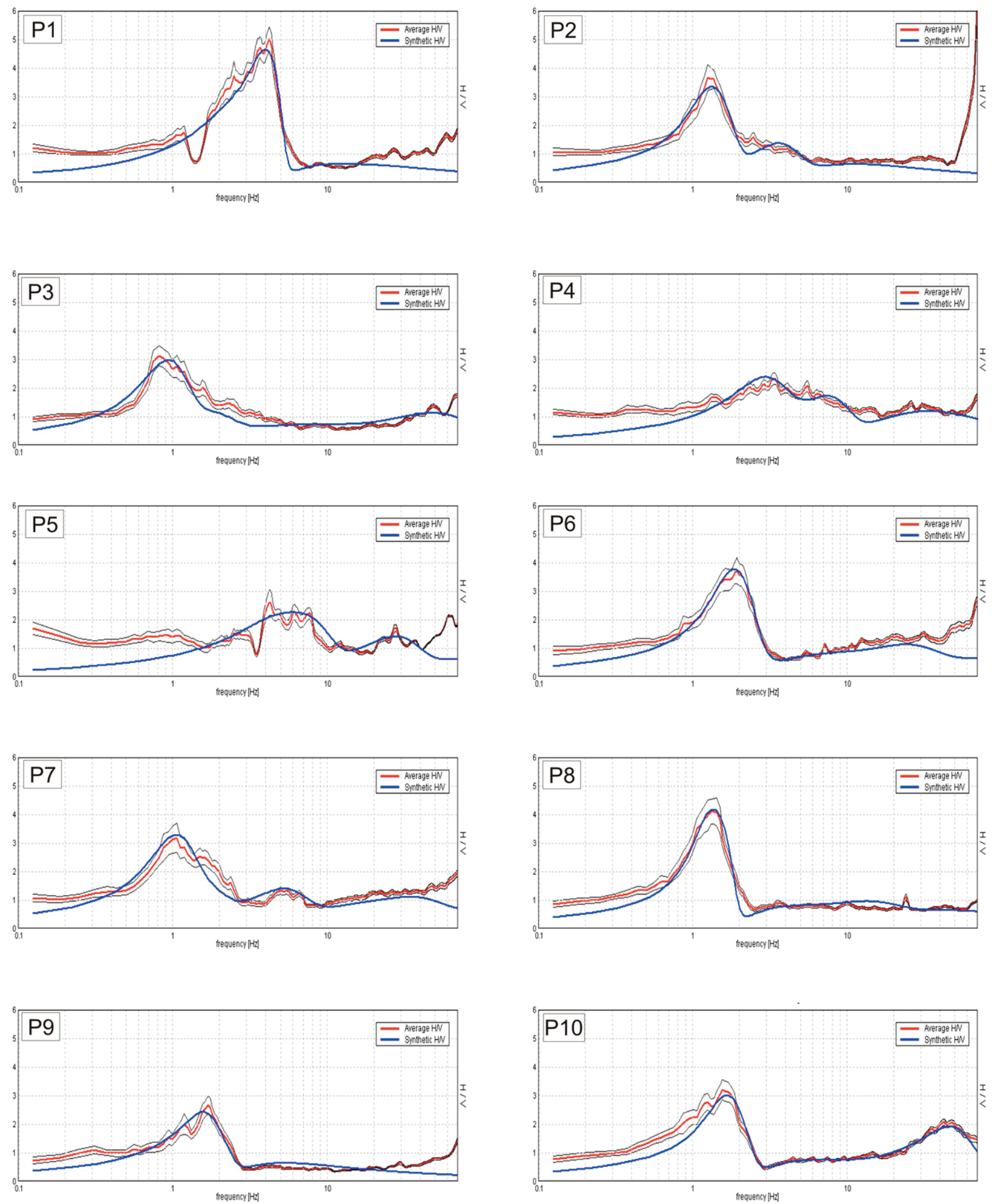

Figure 7. Comparison between observed and synthetic H/V curves: the main peak represents the stratigraphic contact between the Holocene deposits of the Oliveri coastal plain and the metamorphic bedrock. The very high frequency peaks in all of the HVSR curves has no stratigraphic relevance.

antennas with different frequencies allows the subsoil to be examined at different depths and with different resolutions. The use of GPR in archeology has increased over the last few decades, and as a technique, it is largely well documented [Carcione 1996, Pérez Gracia et al. 2000, Conyers 2004, Francese et al. 2009].
In the present survey a Geophysical Survey System Inc. Sir 10B instrument was used, which was equipped with 200 $\mathrm{MHz}$ and $400 \mathrm{MHz}$ monostatic antennas. Where possible, the GPR measurements were acquired along parallel profiles (Figure 6). Analysis of the diffraction hyperbolae resulted in an averaged electromagnetic wave propagation speed in the 
area of $0.07 \mathrm{~m} / \mathrm{ns}$. Considering the recording window (twoway traveltime), the effective investigation depth was about $2 \mathrm{~m}$. The time-distance GPR sections were corrected for the distance and processed by horizontal and vertical filtering and gain compensation. Anomalies were interpreted as target structures if their magnitude, shape, alignment and consistency on parallel and perpendicular lines were confirmed. GPR 3D imaging is a profitable technique to successfully map buried archeological remains [Goodman et al. 1995, Pipan et al. 1999, Piro et al. 2001, Seren et al. 2006, Francese et al. 2009], although generally it costs a lot in terms of data acquisition and post-processing analysis, and it is often time consuming. Nevertheless, 3D profile analysis can define whether a target structure is present or not in the area surveyed.

\subsection{Results}

Ambient noise measurements were carried out at the ground surface at 10 sites distributed over the area investigated (Figure 1b, P1-P10). As a reference point, the P5 acquisition was carried out very close to borehole S2 (see Figure 1b), where detailed information of the local stratigraphy was available (Figure 3) [Trainiti 1997]. Therefore, the stratigraphic data from borehole S2 provide a model of the soil that can be considered as being reliable for the whole of the area investigated. This model is made up of three main layers, each of which is characterized by a range of inferred and reliable Vs values (which generally increase with depth). From the top, these layers show alluvial deposits $(250-400 \mathrm{~m} / \mathrm{s})$, paragneiss with variable degrees of fracture $(500-650 \mathrm{~m} / \mathrm{s})$, and low fractured gneiss $(850-1000 \mathrm{~m} / \mathrm{s})$.

Using the real thicknesses of the layers from the S2 borehole (Figure 3) [Traniti 1997] and the inferred Vs values as input in the calculation sheet of the Grilla software, a good fit between synthetic and experimental HVSR curves from the P5 measurements was obtained (Figure 7). This confirmed the reliability of the inferred Vs values used in the model. The HVSR curve from $\mathrm{P} 5$ shows a plateau in the frequency range of $4 \mathrm{~Hz}$ to $8 \mathrm{~Hz}$, with a small spike at $6 \mathrm{~Hz}$ (Figure 7) that can be ascribed to the contact between Holocene alluvial deposits and the fractured metamorphic rock (Figure 3). Therefore, we used the Vs values in the inversion procedure of the Grilla software to assess the thickness of the Holocene coastal alluvial deposits also for the measurement points where direct stratigraphic data are not available. Several calculations were carried out using different Vs values for the three layers, but we never obtained the same good fits as those shown in Figure 7.

Therefore, we obtained 10 1D seismo-stratigraphic logs of the soil (Figure 8, P1-P10), which show that the depth of the Holocene coastal deposits generally increases from the castle to the shoreline, from about $13 \mathrm{~m}$ to $15 \mathrm{~m}$ below ground level at P4-P5, to about $60 \mathrm{~m}$ below ground level at P3, and to more than $80 \mathrm{~m}$ below ground level at P8 (Figure 8). Intense sedimentation produced the progressive infilling of the basin that started after the 16th century, as reported by historical sources. This is in agreement with the paleotopographic reconstruction of the area, which shows that the shoreline was located further out with respect to the present shoreline. In particular, in the fourth century BC, the Oliveri coastal lowland was a thin strip of land, Oliveri Bay provided a wide inlet that was suitable for the sheltering of the ancient ships, Oliveri Castle was located on the seashore, and the area of Marinello lagoons was covered by the sea [Bottari et al. 2009a].

The areas investigated by active geophysical techniques (in Areas 1, 2 and 3 in Figure 4; see Figure 1b) generally did not fit the characteristics for indirect investigations due to recent heavy anthropogenic changes introduced. Area A3 was the object of recent incomplete building construction, although the terrain in the proximity of this showed minor recasting with respect to the others. GPR profiles were carried out in front and behind the building (Figure 6a), and the most significant profiles are reported in Figure 6b. Of these, profile 4-2 shows the clearest anomalies, which occur at the depth interval of $0-1 \mathrm{~m}$, where the green boxes in Figure $6 \mathrm{~b}$ indicate the suggests of buried walls that appear to be connected to each other by floors (see even reflections at $0.75 \mathrm{~m}$ and $0.5 \mathrm{~m}$ depths). These anomalies along profile 4-2 are elongated downwards (on profile 4-1, they are located at $1 \mathrm{~m}$ depth and acquired at $200 \mathrm{MHz}$ frequency; Figure $6 \mathrm{~b}$ ), but they were not clearly evident on profile 4-3 (not shown). Only the $16 \mathrm{~m}$ to $18 \mathrm{~m}$ anomalies group appeared to be represented on profile 4-4 (not shown), but their connection was not so clear. Nevertheless, the trench excavated for the building construction allowed us to ascribe the anomalies in profiles 4-1 and 4-2 (within reasonable certainty) to the presence of archeological remains, as some of them outcropped from the terrain (i.e. the floor).

The anomalies at $13.5 \mathrm{~m}$ and $16.5 \mathrm{~m}$ along profile $4-9$ in Figure $6 \mathrm{~b}$ provide evidence for the presence of different materials at these locations, which can be interpreted as ancient walls emerging under the entrance road of the building.

\section{Conclusions}

The anthropogenic transformations and environmental decline that has occurred in the area of Oliveri-St. Leo following the construction of the Messina-to-Palermo motorway have strongly rearranged the site and the buried archeological structures. Unfortunately, the archeological complex saved from excavation works carried out in 1971 has been badly damaged by the construction of a private building.

The results obtained using the HVSR method have allowed the definition of the stratigraphy of the Oliveri coastal plain. The increase in the Holocene sedimentary cover north- 
BOTTARI ET AL.

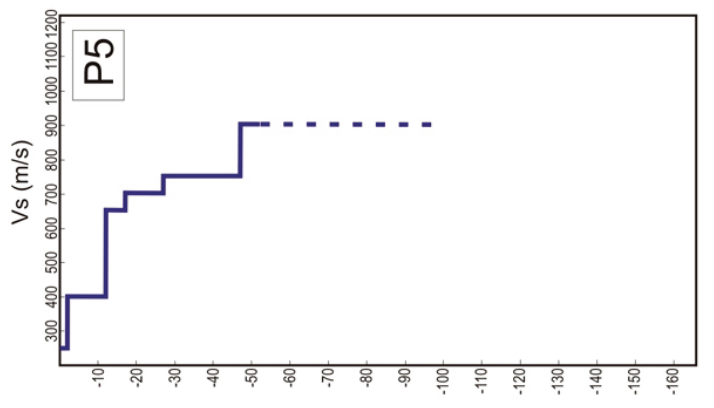

(u) บұdəp pәฺеu!̣s $\exists$

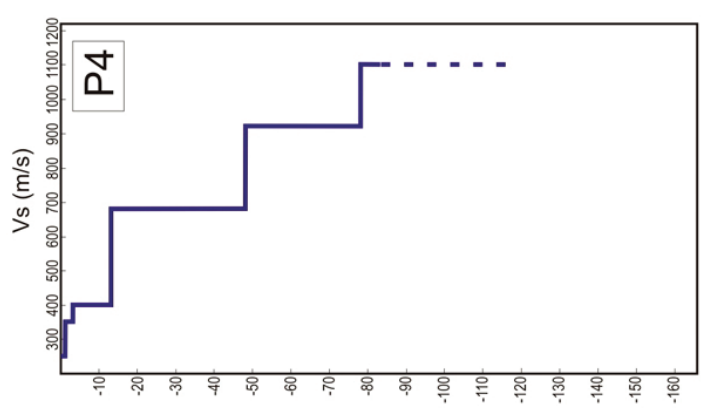

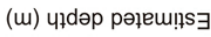

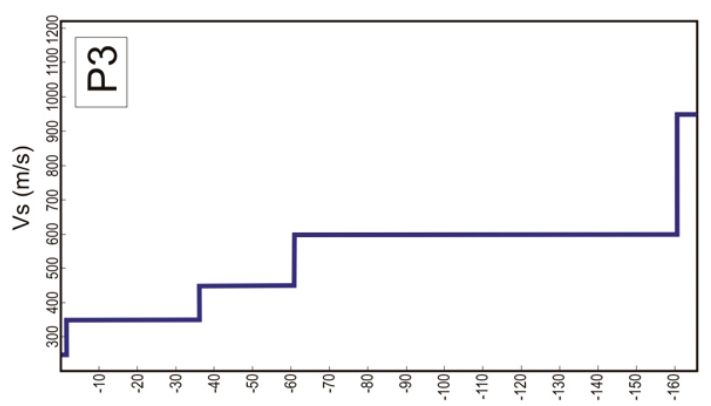

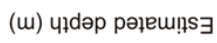

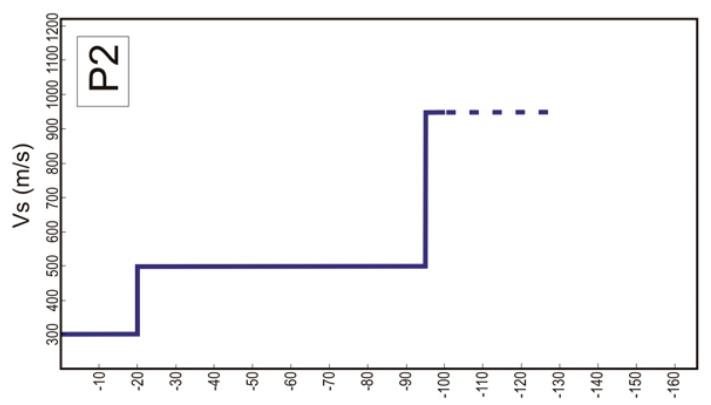

(u) पұdәр рәтеш!ns $\exists$

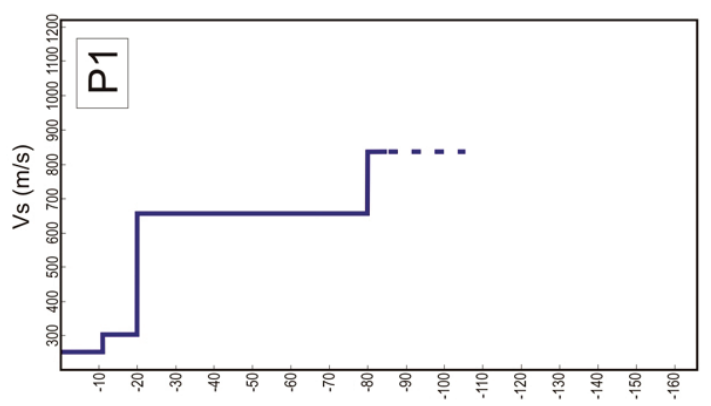

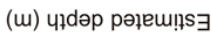

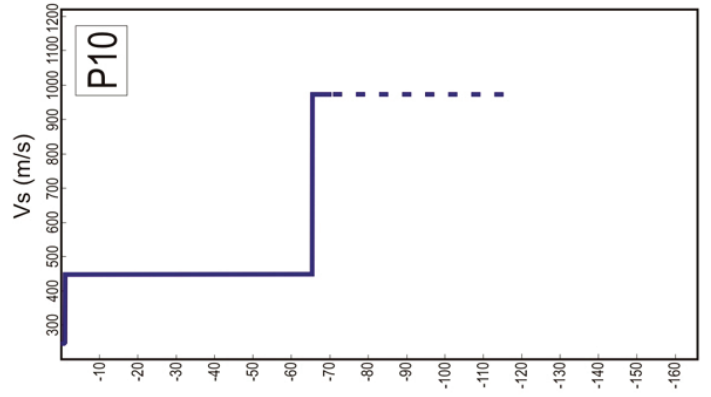

(u) पłdəр рәэеш!̣s $\exists$

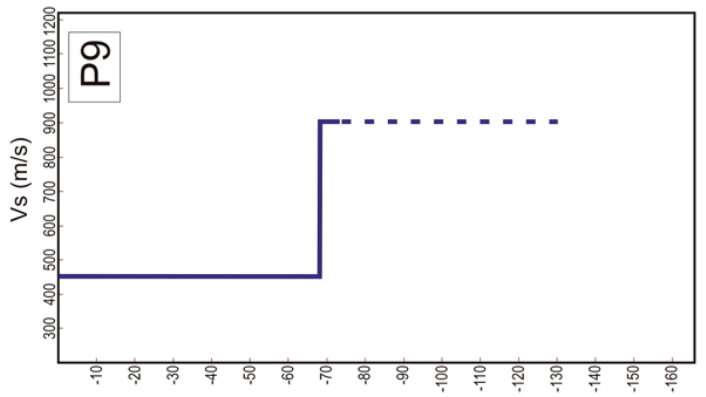

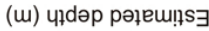

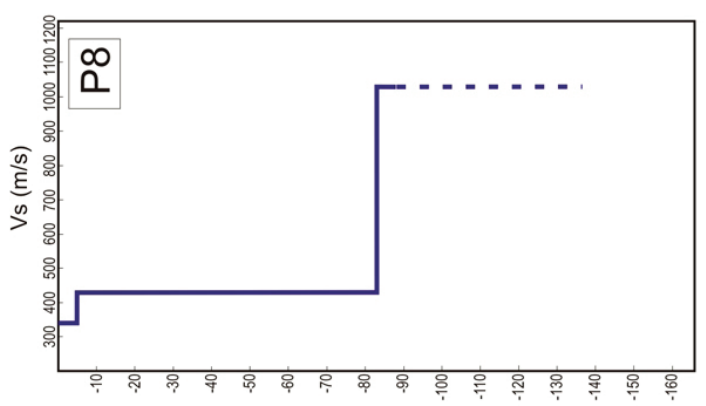

(u) पұdəp рәңеш!̣s $\exists$

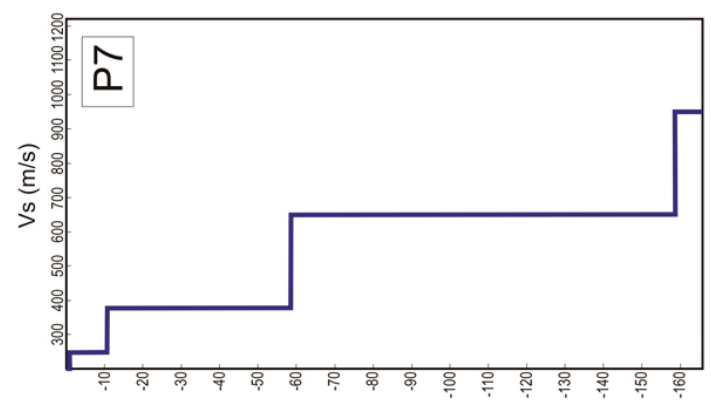

(u) पłdəp pәเеய!̣s $\exists$

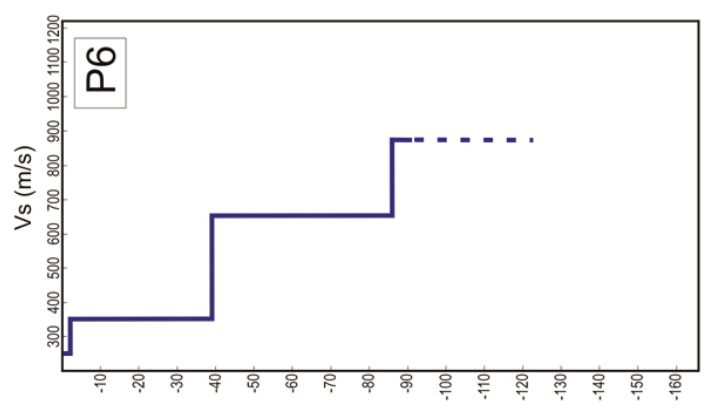

(u) पұdəp pәฺеш!̣s $\exists$ 
east of the castle is consistent with the progradation of the coastline by about $800 \mathrm{~m}$, as documented by historical sources of the 16th century AD [Omodei 1560, Fazello 1574, Camilliano 1584, Spannocchi 1596], and with the presence of a landing place that is dated to the Greek-Roman period and was located between Oliveri Castle and Carruba Valley [Bottari et al. 2009a, and references therein]. The thickness of the alluvial material gives a rough measure of the rate of sediment accumulation that has occurred over the last five centuries.

As an important result, the passive seismic survey validated the reconstruction of the Tindari Promontory DTM that refers to the 4th century BC [Bottari et al. 2009a]. As suggested by the archeologists, the interpretation of GPR anomalies was consistent with the presence of wall structures that are probably ascribable to a maritime Roman villa with annexed baths. Superimposing the GPR data on the DTM for the 4th century $\mathrm{BC}$, the anomalies interpreted as archeological remains used to lie in proximity to the shoreline. The discovery of a Roman villa is of importance. The presence of fragments of mosaic tesserae and cocciopesto floors and decorated plaster, and the lower portion of a marble statue depicting Artemides confirms the importance of this site. This evidence strengthens the hypothesis of a maritime Roman villa in the Oliveri lowland that was connected to the Tindari harbor activities and that probably belonged to Gneo Pompeo. As mentioned by Cicero (IV, 46), the harbor would have been located within the Tindari territory, but outside of the city walls.

\section{References}

Allocca, F., V. Amato, D. Coppola, B. Giaccio, F. Ortolani and F. Pagliuca (2000). Cyclical climatic environmental variations during the Holocene in Campania and Abulia: geoarchaeological and paleoethnological evidence, Memorie della Società Geologica Italiana, 55, 345-352.

Annan, A.P., and S.W. Cosway (1992). Ground Penetrating Radar Survey Design, In: Proceedings of Symposium on the Application of Geophysics to Engineering and Environmental Problems SAGEEP'92, (Oakbrook, IL, USA, 1992), 329-351.

Antonioli, F., L. Ferranti, K. Lambeck, S. Kershaw, V. Verrubbi and G. Dai Pra (2006). Late Pleistocene to Holocene record of changing uplift rates in southern Calabria and northeast Sicily (southern Italy, central Mediterranean Sea), Tectonophysics, 422, 23-40.

Arlotta, G. (1996). Patti prima di Patti - Uomini Monumenti e Santi, Patti: Associazione Teatro-Cultura Beniamino Joppolo.

Atzori, P., and L. Vezzani (1974). Lineamenti petrografici strutturali della catena peloritana, Geologica Romana, 13, 21-27.

Basile, V., M.T. Carrozzo, S. Negri, L. Nuzzo, T. Quarta and
A.V. Villani (2000). A ground-penetrating radar survey for archaeological investigations in an urban area Lecce (Italy), J. Appl. Geophys., 44, 15-32.

Benson, A.K. (1995). Application of ground-penetrating radar in assessing some geological hazards: example of groundwater contamination, faults, cavities, J. Appl. Geophys., 33, 177-193.

Bottari, C., M. D'Amico, M. Maugeri, G. D'Addezio and B. Privitera (2009a). Location of the ancient Tindari harbour from geoarchaeological investigations (NE Sicily), Environ. Archaeol., 14, 37-49.

Bottari, C., M. D'Amico, M. Maugeri, G. D'Addezio, M. Marchetti, S. Urbini and B. Privitera (2009b). On the tracks of the ancient harbour of Tindari (NE, Sicily): geoarchaeological evidence, Méditerranée, 112, 69-74.

Camilliano, C. (1584). Descrizione delle Marine del Regno di Sicilia; edition consulted: Gioacchino Di Marzo, Biblioteca Storica e Letteraria di Sicilia, vol. 24, Palermo 1874, p. 141.

Carcione, J. M. (1996). Ground-penetrating radar simulation for archaeological applications, Geophys. Prospect., 44, 871-888.

Castellaro, S., F. Mulargia and L. Bianconi (2005). Passive seismic stratigraphy: a new efficient, fast and economic technique, Geologia tecnica e ambientale, 3, 76-102.

Cicero (70 BC). Actio in Verrem, IV, 46.

Columba, G.M. (1906). I porti della Sicilia, In: Ministero della Marina, Monografia storica dei porti dell'antichità nella penisola italiana, Roma, Officina Poligrafica Italiana, 232-357.

Consolo Langher, S.N. (1977). Vita economica di Tindari, Archivio Storico Messinese, 38, 161-168.

Conyers, L.B. (2004). Ground-Penetrating Radar for Archaeology, Walnut Creek, AltaMira Press, 218 pp.

Daniels, D.J. (1996). Surface-Penetrating Radar. The Institute of Electrical Engineers, London, Institution of Electrical Engineers, $296 \mathrm{pp}$.

Fazello, T. (1574). Storia di Sicilia; edition consulted: Catania, Dafni, 1985.

Francese, R.G., E Finzi and G. Morelli (2009). Three-dimensional high resolution multi-channel radar investigation of a Roman village in northern Italy, J. Appl. Geophys., 67, 44-51.

Franco, L. (1996). Ancient Mediterranean harbours: a heritage to preserve, Intl. J. Naut. Archaeol., 11, 305-318.

Goodman, D., Y. Nishimura and J.D. Rogers (1995). GPR time slices in archeological prospection, Archaeol. Prospect., 2, 85-89.

Ibs-von Seht, M. and J. Wohlenberg (1999). Microtremor measurements used to map thickness of soft sediments, B. Seismol. Soc. Am., 89, 250-259.

Jol, H.M. and D.G. Smith (1992). Ground Penetrating Radar: Recent Result, Canadian Society of Exploration Geo- 
physicists Recorder, 17, 15-20.

Lambeck, K. and A. Purcell (2005). Sea-level change in the Mediterranean Sea since the LGM: model predictions for tectonically stable areas, Quaternary Sci. Rev., 24, 19691988.

Lentini, F. and L. Vezzani (1975). Le unità mesocenozoiche della copertura sedimentaria del basamento cristallino peloritano (Sicilia nord-orientale), Bollettino della Società Geologica Italiana, 94, 537-554.

Lentini, F., S. Catalano and S. Carbone (2000). Carta geologica della provincia di Messina. Firenze, SELCA.

Marriner, N. and Morhange, C. (2007). Geosciences of ancient Mediterranean harbours, Earth-Sci. Rev., 80, 137-194.

Nakamura, Y. (1989). A method for dynamic characteristics estimates of subsurface using microtremor on the ground surface, Quarterly Report of Railway Technical Research Institute, 30, 25-30.

Nakamura, Y. (2000). Clear identification of fundamental idea of Nakamura's technique and its applications, In: Proceeding of the 12th WCEE meeting (Auckland, New Zealand), 8 pp.

Nogoshi, M. and T. Igarashi (1970). On the propagation characteristics of microtremors, J. Seismol. Soc. Japan, 23, 264-280.

Nogoshi, M. and T. Igarashi (1971). On the amplitude characteristics of microtremors (part 2), J. Seismol. Soc. Japan, 24, 26-40.

Omodei, A.G.F. (1560). Descrizione della Sicilia nel secolo XVI per Messer Giulio Filoteo Omodei; edition consulted: Gioacchino Di Marzo, Biblioteca Storica e Letteraria di Sicilia, vol. 25, Palermo 1876, pp. 1-363.

Ortolani, F. and S. Pagliuca (1994). Variazioni climatiche e crisi dell'ambiente antropizzato, Il Quaternario, 7, 351356.

Pérez Gracia, V., J.A. Canas, L.G. Pujades, J. Clapés, O. Caselles, F. Gracìa and R. Osorio (2000). GPR survey to confirm the location of ancient structures under the Valencian Cathedral (Spain), J. Appl. Geophys., 43, 167-174.

Pipan, M., L. Baradello, E. Forte, A. Prizzon and I. Finetti (1999). Two-dimensional and 3-D processing and interpretation of multi-fold ground penetrating radar data: a case history from an archaeological site, J. Appl. Geophys., 41, 271-292.

Piro, S., D. Goodman and Y. Nishimura (2001). High-resolution ground penetrating radar survey at Forum NovumVescovio: studying urbanism in the Tiber Valley, J. Roman Archaeol., 14, 59-79.

Rumsby, B. and M.G. Macklin (1996). River response to the last neoglacial (the 'Little Ice Age') in northern, western and central Europe, In: J. Branson, AG. Brown and K. Gregory (eds.), Global Continental Changes: the Context of Palaeohydrology (Special Publication 115), London, Geological Society, 217-233.
Scaramuzza, V. (1937). Publican Societes in Sicily in 73-71 BC, Classical Philology, 32, 152-155.

Seren, S., A. Eder-Hinterleitner, P. Melichar and W. Neubauer (2006). New results on comparison of different GPR systems and antenna configurations at the Roman Site Carnutum, In: Proceedings of Near Surface 2006 meeting, 12th European Meeting of Environmental and Engineering Geophysics, Helsinki.

Sesame project (2004). Guidelines for the Implementation of the H/V Spectral Ratio Technique on Ambient Vibrations: measurements, processing and interpretation, Sesame European research project WP12 - Deliverable D23.12, European Commission - Research General Directorate, Project No. EVG-CT-2000-00026 SESAME, December 2004, 62 pp.; http: / sesame-fp5.obs.ujf-grenoble.fr/ Delivrables/Del-D23-HV_User_Guidelines.pdf.

Spannocchi, T. (1596). Descripción de las marinas de todo el Reino de Sicilia, Ms. 788, Biblioteca Nacional de Madrid; see C. Polto (ed.), La Sicilia di Tiburzio Spannocchi: una cartografia per la conoscenza e il dominio del territorio nel secolo XVI, Firenze, Istituto Geografico Militare, 2001.

Trainiti, S. (1997). Studio idrogeologico della zone in cui ricade il pozzo Gelsi di proprietà comunale, Manuscript kept at the Comune di Oliveri (Messina), Ufficio Tecnico (technical department of the municipality of Oliveri).

\footnotetext{
${ }^{\star}$ Corresponding author: Carla Bottari, Istituto Nazionale di Geofisica e Vulcanologia, Sezione Roma 2, Rome, Italy; email: carla.bottari@ingv.it.

(C) 2012 by the Istituto Nazionale di Geofisica e Vulcanologia. All rights reserved.
} 